\title{
Konstruktivistička didaktika i neurodidaktika u diskursu reformne pedagogije \\ Teorijska polazišta, dileme i komparacija
}

\author{
Nevenka Maras* \\ nevenka.maras@ufzg.hr \\ Tomislav Topolovčan ${ }^{* * *}$ \\ tomislav.topolovcan@ufzg.hr \\ Milan Matijević**** \\ milan.matijevic@ufzg.hr
}

\author{
https://doi.org/10.31192/np.16.3.9 \\ UDK: 37.022 \\ 37.091 .33 \\ Pregledni članak / Review \\ Primljeno: 17. travnja 2018. \\ Prihvaćeno: 12. srpnja 2018.
}

U radu su kritičko-komparativnom i povijesnom analizom definirani, objašnjeni i dovedeni u odnos koncepti konstruktivističke didaktike te neurodidaktike s pravcima i pokretima reformne pedagogije. Analizom je pokazano da su neka od zajedničkih obilježja konstruktivističke didaktike i neurodidaktike vidljiva u nastavnim strategijama kao što su: učenje istraživanjem, učenje rješavanjem problema, suradničko učenje, djelovanju usmjereno učenje, učenje igrom $i$ projektno učenje. Drugim riječima, u okviru onoga što se naziva nastavom usmjerenom na učenika. Ta obilježja nisu (u potpunosti) noviteti proizašli iz tih koncepata. Ukazuje se da su ta didaktička obilježja formirana još prije više od stoljeća u pravcima i pokretima reformne pedagogije. Opravdano je nuditi zaključak da ono što je označeno kao konstruktivistička nastava već postoji oblikovano u reformnoj pedagogiji. Ali, isto je tako opravdano zaključiti da neuroznanstvena istraživanja, osim što nude nove spoznaje o procesima učenja, potvrduju i didaktičke vrijednosti pravaca i pokreta reformne pedagogije s prijelaza 19. u 20. stoljeće. S obzirom na međusobnu kompatibilnost analiziranih koncepata, poželjno je težiti njihovoj daljnjoj kritičkoj i argumentiranoj sinergiji, a radi unapređenja nastave.

Ključne riječi: didaktika, konstruktivizam, nastava, obrazovna neuroznanost, reformna pedagogija.

* Doc. dr. sc. Nevenka Maras, Učiteljski fakultet, Sveučilište u Zagrebu, Savska cesta 77, HR10000 Zagreb.

* Doc. dr. sc. Tomislav Topolovčan, Učiteljski fakultet, Sveučilište u Zagrebu, Savska cesta 77, HR-10000 Zagreb.

***: Prof. dr. sc. Milan Matijević, Učiteljski fakultet, Sveučilište u Zagrebu, Savska cesta 77, HR10000 Zagreb. 


\section{Uvod}

U posljednja tri desetljeća pobuđen je interes za ono što se naziva konstruktivistička nastava i poučavanje temeljeno na mozgu. ${ }^{1}$ Zahvaljujući spoznajama razvojne psihologije i psihologije učenja (re)afirmirane su strategije učenja usmjerene na učenika. ${ }^{2}$ Time je etablirana platforma za formiranje psihološkog koncepta i teorije učenja u paradigmi konstruktivizma, tj. konstruktivističke (psihološke) teorije učenja. Tim psihološkim spoznajama nanovo su do izražaja došle teorije učenja koje su razvijali Jean Piaget, Lev Vygotsky, Paul Watzlawick, Jerome Bruner i dr., još u prvoj polovici ili polovicom 20. stoljeća. ${ }^{3}$ Nakon toga, 1980-ih godina, formiranjem konstruktivističke psihološke teorije učenja, naglašena je važnost istraživanja mozga, tj. neuroznanosti. ${ }^{4} \mathrm{U}$ tom pogledu, stručnjake u području istraživanja mozga zaintrigirao je način odvijanja procesa učenja te što istraživanja mozga mogu otkriti o tome.

Neuroznanost označava niz psiholoških (kognitivnih), bioloških i medicinskih znanstvenih disciplina koje proučavaju čovjeka s različitih, sebi svojstvenih aspekata, a prvenstveno na razini funkcioniranja mozga i živčanog sustava. ${ }^{5}$ Spoznaje tih neuroznanstvenih disciplina ukazale su da su procesi učenja prirođeni ljudskoj vrsti. Pokazalo se, također, da je (biološki gledano) učenje prirođen mehanizam na temelju kojeg funkcionira ljudski mozak. ${ }^{6}$ Drugim riječima, pokazuje se da je način funkcioniranja mozga neurološka osnova nastave usmjerene na učenika. ${ }^{7}$

Spoznajama psihologije te neuroznanosti počelo se ukazivati na neka nova ili reafirmirati već postojeća obilježja učenja, nastave te odgoja i obrazovanja. Dijete je (ponovno) stavljeno u centar pažnje. Reafirmiran je naglasak prilago-

${ }^{1}$ Usp. Renate NUMMELA CAINE, Geoffrey CAINE, Making connections. Teaching and the human brain, Alexandria, ASCD, 1994; John GEAKE, The brain at school. Educational neuroscience in the classroom, Berkshire, The McGraw-Hill \& Open University Press, 2009; Ulrich HERRMANN (ur.), Neurodidaktik. Grundlagen und Vorschläge für gehirngerechtes Lehren und Lernen, Weinheim und Basel, Beltz Verlag, 2009; OECD, Understanding the brain. The birth of a learning science, Paris, 2007; Kersten REICH, Konstruktivistische Didaktik, Weinheim und Basel, Beltz, 2006; Ewald TERHART, Konstruktivismus und Unterricht. Gibt es einen neuen Ansatz in der Allgemeinen Didaktik?, Zeitschrift für Pädagogik, 45 (1999) 5, 629-647; Sigmund TOBIAS, Thomas M. DUFFY (ur.), Constructivist instruction. Success or failure?, New York, Routledge, 2009; Tomislav TOPOLOVČAN, Višnja RAJIĆ, Milan MATIJEVIĆ, Konstruktivistička nastava. Teorija i empirijska istraživanja, Zagreb, Učiteljski fakultet Sveučilišta u Zagrebu, 2017.

${ }^{2}$ Usp. Laura E. BERK, Child development, Boston, Pearson, 2006; Martyn LONG i dr., The psychology of education, London - New York, Routledge, 2011.

3 Usp. Terhart, nav. dj., 637; Topolovčan, Rajić, Matijević, nav. dj., 46.

${ }^{4}$ Usp. Michael S. GAZZANIGA (ur.), The cognitive neuroscience, Cambridge, MIT Press, 2009; Herrmann, nav. dj; ; Brian KOLB, Ian Q. WHISHAW, Fundamentals of human neuropsychology, New York, W. H. Freeman, 2009.

${ }^{5}$ Usp. John P. J. PINEL, Biopsychology, Boston, Allyn and Bacon, 2000.

${ }^{6}$ Usp. Nummela Caine, Caine, nav. dj.

${ }^{7}$ Usp. OECD, Understanding the brain..., 26, 52, 172 . 
đavanja nastave učeniku (individualizacija). Drugim riječima, počelo se govoriti o djetetu, tj. učeniku kao subjektu koji je samosvjestan, društven, suradnički, samoreguliran i aktivan participator u procesima nastave te odgoja i obrazovanja. ${ }^{8}$ Time je bitno pridoneseno težnji promjene uloga učenika i učitelja $u$ nastavi, učenju i obrazovanju, a to je ujedno bilo jedno od obilježja reformne pedagogije s kraja 19. stoljeća. ${ }^{9}$

Iako su psihološke i neuroznanstvene spoznaje bitne, ambiciozne, optimistične i euforične, pojavljuju se neke dileme, pa se valja pozvati na njihovu kritičku i argumentiranu didaktičku interpretaciju i kontekstualizaciju. U tom pogledu prvenstveno se misli na njihovu originalnost, pogotovo u kontekstu analize povijesti didaktike. Zato se nameće pitanje jesu li konstruktivistička nastava i nastava temeljena na mozgu zaista novi pristupi u didaktici ili su ti koncepti poznati već otprije, ali pod drugim nazivima, a u ovom slučaju u obliku didaktičkih elemenata pravaca i pokreta reformne pedagogije?

Stoga je cilj ove teorijsko-komparativne i povijesne analize pružanje odgovora je li riječ o konstruktivističkoj didaktici i neurodidaktici kao bitno novim pristupima u nastavi ili možemo posegnuti za didaktičkim elementima reformne pedagogije kao njihovim relevantnim objašnjenjima? U daljnjem tekstu će nastava, poučavanje i učenje biti detaljnije definirano i objašnjeno s aspekta konstruktivizma te kako ga objašnjavaju spoznaje neuroznanosti. Potom će biti objašnjeni didaktički elementi pravaca i pokreta reformne pedagogije, a na kraju komparacija ova tri koncepta te pružene interpretacije i zaključci njihove usporedbe.

\section{Konstruktivistička didaktika}

Konstruktivizam je moguće definirati kao konstruiranje percepcije stvarnosti i znanja na temelju individualnih aktivnosti te interakcije s fizičkom i društvenom okolinom. ${ }^{10}$ Valja naglasiti da se time ne tvrdi da ne postoji objektivna stvarnost, već da je nije moguće dokraja objektivno spoznati. Konstruktivizam je epistemološka (filozofska), psihološka i didaktička teorija. ${ }^{11}$ Iako se na prvi

${ }^{8}$ Usp. Dubravka MALEŠ (ur.), Nove paradigme ranoga odgoja, Zagreb, Filozofski fakultet Sveučilišta u Zagrebu i Zavod za pedagogiju, 2011.

${ }^{9}$ Usp. Erenhard SKIERA, Reformpädagogik in Geschichte und Gegenwart. Eine kritische Einführung, München, Oldenburg, 2010.

${ }^{10}$ Usp. Catherine TWOMEY FOSNOT, Randall STEWART PERRY, Constructivism. A psychological theory of learning, u: Catherine TWOMEY FOSNOT (ur.), Constructivism. Theory, perspectives and practice, New York, NY, Teacher College Press, 2005, 8-35, 10-11 i 33 35; Glasersfeld VON ERNST, Radical constructivism. A way of knowing and learning, London, Routledge Publication, 2003.

${ }^{11}$ Usp. Gellof KANSELAAR i dr., New technologies, u: Robert-Jan SIMONS, Jos VAN DER LINDEN, Tom DUFFY (ur.), New learning, Dodrecht, Kluwer Academic Publishers, 2002, 5582,58 . 
pogled on doima kao relativno novija teorija, ipak ima svoju dugu povijest. Ideja konstruktivizma datira još iz doba prije antičke Grčke, prvenstveno u Ksenofanovoj spoznaji (Boga), a potom i kod Pirona iz Elide. Zatim, ideje konstruktivizma su vidljive u tumačenjima Protagore i sofista u gledanju na čovjeka kao mjerila svih stvari. Time je ukazano da je spoznaja i istina tek ono što je čovjeku dokučivo i što čovjek odredi. Ove su ideje vidljive i kod Heraklita koji je prepoznao »unutarnja stanja « vjerovanja od vanjskih činjenica. ${ }^{12}$ Također i kod Sokrata. ${ }^{13}$ I Gautama Buddha je u 5. st. pr. Kr. ukazivao na to da su ljudi ono što misle da jesu, čime je ukazivao na konstruktivističku spoznaju samoga sebe. Potom, i Platon je govorio o individualnim spoznajama stvarnosti. ${ }^{14}$ Ideje konstruktivizma vidljive su i Bizantu u vidu »negativne teologije«, isto kao što su vidljive u taoizmu te katoličkom nauku i učenju Ivana Skota Eriugene iz 9. stoljeća, a koji je anticipirao ideje Kanta i Decartesa. ${ }^{15}$ Kasnije su konstruktivističke ideje vidljive i kod Lockea, Berkeleya, Humea te Giambattiste Vicoa. Bitan doprinos razvoju filozofske teorije konstruktivizma dao je i Immanuel Kant. ${ }^{16}$ Početkom 20. stoljeća, konstruktivizam se odvaja od filozofskog i metafizičkog shvaćanja te je etabliran u vidu psiholoških i didaktičkih teorija. Tome su doprinijeli neurobiološki radovi Maturane i Varele, psihološke studije Jeana Piageta i Leva Vygotskog, teorija komunikacije Paula Watzlawicka, pedagoške ideje Johna Deweya te Luhmannova teorija sustava. ${ }^{17}$

Konstruktivizam se, uglavnom, dijeli na dvije vrste: radikalni i socijalni. Uz ove dvije vrste govori se još i o personalnom, kognitivnom i kritičkom..$^{18}$ Radikalni konstruktivizam ukazuje na to da je znanje individualno konstruirano kao produkt interakcije pojedinca s okolinom (fizičkom). S druge strane,

\footnotetext{
${ }^{12}$ Usp. von Glasersfeld, nav. dj., 26-52; Geoffrey S. KIRK, Heraclitus. The cosmic fragments, Cambridge, Cambridge University Press, 1896; PLATON, Država, Zagreb, Naklada Jurčić, 2009; Alan PRICHARD, John WOOLLARD, Psychology for the classroom. Constructivism and social learning, London, Routledge, 2010, 2.

${ }^{13}$ Usp. Prichard, Woolard, nav. dj., 2-3; Kirk, nav. dj.

${ }^{14}$ Usp. Prichard, Woolard, nav. dj., 2-3.

${ }^{15}$ Usp. von Glasersfel, nav. dj.; Prichard, Woollard, nav. dj., 2-3; Giambattista VICO, De antiquissima Italorum sapientia, Napulj, Stamperia de'Classici Latini, 1710; Giambattista VICO, Principi di scienza nuova, Garden City, New York, Anchor Books.

${ }^{16}$ Usp. isto; Immanuel KANT, Kritika čistog uma, Beograd, Kultura, 1970; Stefan SCHWEISER, In history of ideas, constructivist pedagogy stems from German idealism, Electroneurobiologia, 55 (2007) 4, 63-95.

${ }^{17}$ Usp. John DEWEY, Democracy and Education. An Introduction to the Philosophy of Education, Delhi, Aakar Books, 1990; Humberto R. MATURANA, Francisco J. VARELA, The Tree of Knowledge. The Biological Roots of Human Understanding, Boston, Shambala, 1992; Niklas LUHMANN, Soziale Systeme. Grundriss einer allgemeinen Theorie, Frankfurt a. M., Suhrkamp, 1984; Jean PIAGET, Judgement and the Reasoning in the Child, London, Routledge, 2002; Jean PIAGET, Psychology of the intelligence, London, Routledge, 2005; Lev VYGOTSKY, Thought and language, Cambridge, MA, MIT Press, 1986; Terhart, nav. dj.; Topolovčan, Rajić, Matijević, nav. dj., 39-41; Paul WATZLAWICK, The Invented Reality. How Do We Know What We Believe We Know?, New York, Norton and Co, 1984; Paul WATZLAWICK, Wie wirklich ist die Wirklichkeit? Wahn - Täuschung - Verstehen, München, Piper Verlag, 2003.

${ }^{18}$ Usp. Topolovčan, Rajić, Matijević, nav. dj., 49-51.
} 
socijalni tvrdi da je znanje i dalje individualno konstruirano, ali u interakciji is društvenom okolinom, odnosno u interakciji i komunikaciji s drugim ljudima te da je kulturološki uvjetovano. Zato se na didaktičkoj razini vode rasprave o odnosu direktnog poučavanja učitelja te samostalnog i suradničkog učenja učenika. ${ }^{19}$

Konstruktivističko učenje je moguće objasniti kao samoregulirano, situacijsko i suradničko konstruiranje vlastita znanja na temelju vlastitih predznanja, aktivnosti, iskustava, emocija i sl. ${ }^{20}$ Obilježja konstruktivističkog učenja (i nastave) navedena u literaturi: aktivan proces; aktivno prilagođavanje; situacijsko i kontekstualno učenje; znanje nije pasivno preneseno i primljeno, već konstruirano od strane onog koji uči; znanje je osobno: znanje je društveno konstruirano (u društvenom kontekstu); temeljni je proces stvaranja smisla i razumijevanja svijeta; iskustvo i prijašnja razumijevanja su ključna za učenje; za učenje je značajna društvena interakcija; rješavanje smislenih, otvorenih i izazovnih problema. ${ }^{21}$

Konstruktivistička nastava diferencira procese učenja, poučavanja te nastave. Posebice zato što je evidentno da je moguće učiti bez poučavanja (samostalno, samoregulirano, informalno, prirodno, samoučenje), da je moguće učiti i u okolnostima poučavanja, da je moguće poučavati a da se ne postigne nečije učenje, te da je moguće učiti i ono što nije eksplicitno poučavano (skriveni kurikul). ${ }^{22}$ Upravo takvo razlikovanje moguće je zahvaljujući pomaku prema konstruktivističkoj nastavi. Time nastava označava zajedničku i ciljanu aktivnost učenika i učitelja. Shodno tome, poučavanje je moguće definirati kao organizaciju aktivnosti učenja nekog sadržaja gdje učenik, radeći te aktivnosti samostalno i suradnički, konstruira vlastita znanja. Stoga je obilježja konstruktivističke nastave moguće objasniti ovako: primarni cilj nastave je suradničko konstruiranje značenja; učitelj uvažava učenikovo mišljenje i emocije; učenici i učitelj zajedno poučavaju i uče; društvena interakcija dominira u nastavi; $u$ kurikulu su implementirane kulture učenika; uz intelektualne, prihvaćene su

\footnotetext{
${ }^{19}$ Usp. Tobias, Duffy, nav. dj.

${ }^{20}$ Usp. Fosnot, Perry, nav. dj., 10-11, 33-35; Tomislav TOPOLOVČAN, Art-based research of constructivist teaching, Croatian Journal of Education, 18 (2016) 4, 1141-1172, 1146; Tomislav TOPOLOVČAN, Milan MATIJEVIĆ, Critical thinking as a dimension of constructivist learning. Some of the characteristics of students of lower secondary education in Croatia, Center for Educational Policy Studies Journal, 7 (2017) 3, 47-66, 52; Topolovčan, Rajić, Matijević, nav. dj., 13.

${ }^{21}$ Usp. Kaya YILMAZ, Constructivism. Its theoretical underpinnings, variations, and implications for classroom instruction. Educational Horizons, 76 (2008) 3, 161-172, 167-168.

${ }^{22}$ Ovdje valja ukazati da, bez obzira što postoji diferencijacija procesa »poučavanja « $\mathrm{i}$ »učenja«, u didaktičkom se aspektu nikako ne odmiče od važnosti »nastave«. S tog aspekta upravo se potvrđuje da je (školsko) učenje uvijek smislen, vrijednosno određen, društven, kulturološki, socijalizacijski i komunikacijski odnos učenika i učitelja, a to nije moguće svesti samo na procese učenja i poučavanja, već se zbiva u nastavi.
} 
i učenikove fizičke i čuvstvene potrebe; vrednuje se individualni napredak pojedinca. ${ }^{23}$

Analizirajući te sumirajući sva obilježja konstruktivističkog nastave, moguće je ukazati na didaktičke strategije učenja, ${ }^{24}$ a one su: učenje istraživanjem i otkrivanjem; učenje rješavanjem problema; učenje igrom; projektno učenje; suradničko učenje; djelovanju usmjereno učenje. ${ }^{25}$

Vidljivo je da konstruktivistička didaktika naglašava pomak od didaktike poučavanja prema didaktici učenja. Učenje je ono što je bitno u nastavi i obrazovanju, pa se govori o nastavi usmjerenoj na učenika ili novoj kulturi učenja. ${ }^{26}$ Time se učenik promatra kao samosvjestan, aktivan i djelujući subjekt vlastitog procesa učenja i nastave, što potencira zaokret u smjeru novih paradigmi djeteta i djetinjstva. ${ }^{27}$

\section{Neurodidaktika}

Istraživanja mozga nisu novina posljednjih nekoliko desetljeća. Istraživački interes za mozak poznat je od vremena prije Krista te u srednjem vijeku, ali je intenziviran u 19. stoljeću, a naročito u 20 . stoljeću. ${ }^{28} \mathrm{U}$ posljednjih nešto više od tri desetljeća istraživanja mozga su dobila bitno drugačiju dimenziju zahvaljujući novim tehnologijama skeniranja. Nove tehnologije skeniranja su omogućile istraživanje mozga pomoću pozitronske emisijske tomografije (PET) i metode magnetske rezonancije (MRI). ${ }^{29}$ Dotadašnja su se istraživanja mozga obavljala na životinjama ili preminulim ljudima. Od razvoja novih tehnologija

${ }^{23}$ Usp. Penny OLDFATHER i dr., Learning through children's eyes. Social constructivism and the desire to learn, Washington, DC, American Psychological Association, 1998, 22.

${ }^{24}$ Ovdje se pod strategijama »učenja « podrazumijeva i pojam »nastave« (iako stručno gledano nisu sinonimi), pa je moguće govoriti o problemskoj nastavi, istraživačkoj nastavi, suradničkoj nastavi, projektnoj nastavi i dr.

${ }^{25}$ Usp. Topolovčan, Rajić, Matijević, nav. dj., 58, 116.

${ }^{26}$ Usp. Stjepan RODEK, Novi mediji i nova kultura učenja, Napredak, 152 (2011) 1, 9-28; Simons, Van Der Linden, Duffy (ur.), nav. dj.

${ }^{27}$ Usp. Maleš, nav. dj.

${ }^{28}$ Usp. Miloš JUDAŠ, Iz Desetljeća mozga u Stoljeće uma, u: Mislav-Stjepan ŽEBEC i dr. (ur.), Mozak i um - trajni izazov čovjeku, Zagreb, Institut društvenih znanosti Ivo Pilar, 2006, 2754; Melita KOVAČEVIĆ, Neurolingvistika kao poveznica mozga i uma. Teorija, istraživanja i primjena, u: Mislav-Stjepan ŽEBEC i dr. (ur.), Mozak i um - trajni izazov čovjeku, Zagreb, Institut društvenih znanosti Ivo Pilar, 2006, 67-78; Selma SUPEK, Metode za funkcionalno oslikavanje mozga čine um vidljivima, u: Mislav-Stjepan ŽEBEC i dr. (ur.), Mozak i um - trajni izazov čovjeku, Zagreb, Institut društvenih znanosti Ivo Pilar, 2006, 55-66.

${ }^{29}$ Usp. Bernard J. BAARS, Nicole M. GAGE (ur.), Fundamentals of cognitive neuroscience. A beginner's guide, Oxford, Academic Press, 2013; Eric JENSEN, Teaching with the brain in mind, Alexandria, VA, ASCD, 2005, 2-4; Jane McGEEHAN, Brain-compatible learning, Green teacher, 64 (2001) 7-12, 7; Robert STERNBERG, Kognitivna psihologija, Jastrebarsko, Naklada Slap, 2005. 
skeniranja provedena su brojna istraživanja u području neuroznanosti o ljudskom razvoju, ponašanju i djelovanju s bitno drugačijim novim spoznajama. ${ }^{30}$

Paralelno se uz istraživanja načina funkcioniranja ljudskog mozga pojavio i interes za objašnjavanje učenja, poučavanja, nastave i obrazovanja na temelju tih spoznaja. ${ }^{31}$ Drugim riječima, nastojalo se rezultatima istraživanja mozga objasniti ljudsko učenje te oblikovati okolinu učenja i unaprijediti nastavu. U tom se pogledu počelo govoriti o učenju temeljenom na mozgu (engl. brainbased learning), poučavanju s mozgom na umu (engl. teaching with brain in mind), učenju i poučavanju primjerenom mozgu (engl. brain compatible learning/teaching) te neurodidaktici (njem. Neurodidaktik). ${ }^{32}$ Među prvima se ovom problematikom počeo baviti Leslie Hart u svojoj knjizi »Human brain and human learning « iz 1983. godine, a on je zaslužan i za formiranje pojma "primjerenost mozgu (engl. brain-compatible) u kontekstu obrazovanja. ${ }^{33}$

Radi organiziranja poučavanja i nastave u skladu s neuroznanstvenim spoznajama kako mozak uči i funkcionira, reagirale su i neke međunarodne organizacije. Tako je OECD ${ }^{34}$ izdao dvije knjige o neuroznanstvenim spoznajama o učenju: »Understanding the brain. Towards a new learning science ${ }^{35} \mathrm{i} \gg$ Understanding the brain. The birth of a learning science ${ }^{36}$ Također, danas više nije

\footnotetext{
${ }^{30}$ Usp. Baars, Gage, nav. dj.; Donna COCH, Kurt W. FISCHER, Geraldine DAWSON (ur.), Human behavior, learning, and the development of the brain, New York, Guilford Press, 2007; Gazzaniga, nav. dj.; Miloš JUDAŠ, Ivica KOSTOVIĆ, Temelji neuroznanosti, Zagreb, MD, 1997; Kolb, Whishaw, nav. dj.; Charles A. NELSON, Monica LUCIANA (ur.), Handbook of developmental cognitive neuroscience, Cambridge, MIT Press, 2008.

${ }^{31}$ Usp. Caine, Caine, nav. dj.; Laura ERLAUER, The brain-compatible classroom. Using what we know about learning to improve teaching, Alexandria, VG, ASCD, 2003; Geake, nav. dj.; Jensen, nav. dj.; Herrmann, nav. dj.; Katryn, E. PATTEN, Stephen R. CAMPBELL (ur.), Educational neuroscience. Initiatives and emerging issues, West Sussex, Wiley-Blackwell, 2011; Vladimira VELIČKI, Tomislav TOPOLOVČAN, Neuroznanost, nastava, učenje i razvoj govora, u: Milan MATIJEVIĆ (ur.), Nastava $i$ škola za net-generacije, Zagreb, Učiteljski fakultet Sveučilišta u Zagrebu, 2017, 77-114.

${ }^{32}$ Usp. Herrmann, nav. dj.; Jensen, nav. dj.; Marlee SPRENGER, Learning and memory. The brain in action, Alexandria, ASCD, 1999; McGeehan, nav. dj.

${ }^{33}$ Usp. McGeehan, nav. dj., 7.

${ }^{34}$ Valja napomenuti da postoje opravdane i argumentirane kritike uloge OECD koji nije primarno formiran za pitanja odgoja i obrazovanja, već ekonomije, gospodarstva i politike, a koji se ipak bavi obrazovnim politikama. Stoga se ukazuje na probleme kao što su standardizacija, psihologizacija, medikalizacija odgoja i obrazovanja te mjerljivost ishoda učenja (u relacijama cilj - sredstvo i ulaganje - dobivanje) radi ekonomizacije i globalizacije obrazovanja i obrazovnih sustava [usp. Tero AUTIO, Curriculum theory in contestation? American curriculum, European didaktik, and Chinese wisdom traditions as hybrid platforms for educational leadership, u: Michael ULJENS, Rose M. YLIMAKI (ur.), Bridging educational leadership, curriculum theory and didaktik, Cham, Springer, 2017, 257-282; Pasi SAHLBERG, Lekcije iz Finske, Zagreb, Školska knjiga, 2012; Daniel TRÖHLER, Languages of education. Protestant legacies, national identities, and global aspirations, New York and London, Routledge, 2011; Daniel, TRÖHLER, Ragnhild BARBAU (ur.), Education systems in historical, cultural, and sociological perspectives, Rotterdam, Sense Publishers, 2011].

${ }^{35}$ Usp. OECD, Understanding the brain. Towards a new learning science, Paris, 2002.

${ }^{36}$ Usp. OECD, Understanding the brain. The birth of a learning science...
} 
ni neuobičajeno da se u udžbenicima ili monografijama o ljudskom učenju ti procesi objašnjavaju dobrim dijelom i s aspekta neuroznanosti. ${ }^{37}$

Što se događa u mozgu te kako funkcionira mozak, a bitno je za organiziranje učenja i nastave? Ovdje ćemo ukratko objasniti taj proces, a za detaljan uvid upućujemo na proučavanje opsežne literature. ${ }^{38}$ Mozak funkcionira na temelju neuronske mreže. Tu mrežu čine stanice i veza među njima. Postoje dvije vrste stanica: neuroni i glija stanice. Veze među neuronima nazivaju se sinaptičke veze (sinapse). Funkcija neurona je provođenje živčanih impulsa, a glija stanice hrane neurone. Neuron se sastoji od tijela, jednog aksona i većeg broja dendrita. Impulse prima dendrit i on ih kroz tijelo neurona usmjerava prema aksonu, a s njega impulsi prelaze na dendrite drugih neurona. U mozgu, neuronima prolaze električni signali koji su produkt veće električne energije. Da bi se stvorila veća električna energija moraju postojati podražaji mozgu. Podražaji mozgu mogu biti vanjski ili unutrašnji - kao što su zanimljive ideje, problemi za rješavanje, poticajna okolina i sl., a koji potiču mozak na reagiranje, tj. stvaranje veće električne energije. Tako stvoreni električni signali putuju neuronom prema njegovom aksonu gdje se ispuštanjem neurotransmitera u sinapsu (između aksona i dendrita) električni signal pretvara u kemijsku reakciju koja u susjednom neuronu, tj. njegovim dendritima, stvara električni impuls. Taj električni signal zatim putuje tijelom neurona do aksona i cijeli postupak se ponavlja. Ovaj se proces simultano događa i ponavlja u svim neuronima cijelo vrijeme. Kada dovoljan broj impulsa prođe kroz sinaptičku vezu ta se veza učvršćuje, pa je potreban slabiji električni naboj impulsa da se on prebaci s aksona na dendrit. Ukratko, taj proces je upravo učenje. Stoga je opravdano kazati da je učenje mehanizam kojim mozak funkcionira. Razvijenost mozga je veća ako ima razvijenije dendrite, a koji se - jer su razvijeniji - mogu vezati na više aksona (koji primaju impulse). Ako mozak nema dovoljno atraktivne i zanimljive podražaje dendriti se ne razvijaju, veze slabe, a s vremenom odumiru i neuroni. ${ }^{39}$

Valja kazati da čovjek dnevnoj gubi od 10.000 do 100.000 neurona (čime se ne ugrožava fiziološka funkcionalnost mozga, jer se procjenjuje da mozak ima više od 100 milijardi, neurona, više od 1000 milijardi glija stanica te više od 100 bilijuna sinaptičkih veza među neuronima. ${ }^{40}$ Nadalje, moguće je kazati da iskustvo određuje broj neurona i sinaptičkih veza (razvijenost dendrita), stoga se

\footnotetext{
${ }^{37}$ Usp. John D. BRANSFORD, Ann L. BROWN, Rodney R. COCKING (ur.), How people learn. Brain, mind, experience, and school, Washington, Nacional Academy Press, 2000; Manfred SPITZER, Lernen. Gehirnforschung und die Schule des Lebens, Heidelberg und Berlin, Spektrum Akademischer Verlag, 2002.

${ }^{38}$ Usp. Gazzaniga, nav. dj.; Jensen, nav. dj.; Judaš, Kostović, nav. dj.; Pinel, nav. dj.; Sprenger, nav. dj.

${ }^{39}$ Usp. Gazzaniga, nav. dj.; Jensen, nav. dj., 8-16; Pinel, nav. dj.

${ }^{40}$ Usp. Jensen, nav. dj., 8-16.
} 
govori i o »plastičnosti mozga «. ${ }^{41}$ Općenito rečeno, struktura mozga se tijekom čovjekova života mijenja (formiranje i učvršćivanje novih sinaptičkih veza te odumiranje nekorištenih neurona). Pojednostavljeno kazano, za razvoj i optimalno funkcioniranje mozga potrebna je obogaćena okolina u obliku problema koje treba riješiti, noviteta, suradnje, igranja, fizičkog kretanja, rada i sl., a ne neaktivnog sjedenja, pukog gledanja i nekomuniciranja.

S aspekta obrazovne neuroznanosti, tj. neurodidaktike, utvrđeno je da frontalna nastava - nastava usmjerena na učitelja, nastava gdje su učenici pasivni, nastava gdje učenici sjede po 45 do 90 minuta te šute i prepisuju sadržaj s ploče (ili power point prezentacije) u bilježnice - nije primjerena za optimalno funkcioniranje mozga. Upravo suprotno, visoku didaktičku vrijednost imaju aktivnosti koje od učenika traže kretanje, istraživanje, druženje, kritičko mišljenje, rješavanje problema, neuspjeh, rad rukama i sl. ${ }^{42}$ Drugim riječima, to su aktivnosti koje su biološki prirođene ljudskom biću, pa je kao proces poželjno organizirati spomenute aktivnosti za postizanje željenih ishoda učenja, tj. rezultata. Ove su aktivnosti prijeko potrebne za funkcioniranje mozga i ljudskog organizma. Spomenuta poželjna obilježja proizlaze iz rezultata neuroznanosti, a na temelju kojih je utvrđeno dvanaest principa kako mozak funkcionira i uči:

1. mozak je kompleksan i adaptivan

2. mozak je društven

3. traženje smisla (značenja) je urođeno

4. traženje smisla (značenja) se pojavljuje prema obrascu

5. emocije su ključne za stvaranje obrazaca

6. mozak istovremeno percipira dijelove i cjelinu

7. učenje uključuje fokusiranu pažnju i perifernu percepciju

8. učenje uključuje svjesne i nesvjesne procese

9. memorira se na više načina

10. učenje je razvoj

11. cjelovito učenje potpomognuto je izazovom, a spriječeno stresom

12. svaki mozak je jedinstveno organiziran. ${ }^{43}$

Ne ulazeći ovdje u detaljniju analizu ovih principa, moguće je samo ukazati na to da su s tim principima u skladu ove strategije učenja: učenje istraživanjem i otkrivanjem; učenje rješavanjem problema; učenje igrom; projektno učenje; suradničko učenje; djelovanju usmjereno učenje. ${ }^{44}$

\footnotetext{
${ }^{41}$ Usp. Marian DIAMON, Janet HOPSON, Čarobno drveće uma. Kako razvijati inteligenciju, kreativnost $i$ zdrave emocije vašeg djeteta od rodenja do adolescencije, Lekenik, Ostvarenje, 2006; Jensen, nav. dj.

${ }^{42}$ Usp. OECD, Understanding the brain. The birth of a learning science...; Jensen, nav. dj.; Velički, Topolovčan, nav. dj., 85.

${ }^{43}$ Usp. Caine, Caine, nav. dj., 87-98.

${ }^{44}$ Usp. Velički, Topolovčan, nav. dj., 109.
} 
Opravdano je naznačiti da se uvažavanjem spoznaja o načinu funkcioniranja mozga ne isključuje pojedinačna uloga naslijeđa ili okoline (učenja). Upravo suprotno, uvažavaju se obje karakteristike, jer je utvrđeno da je za ljudski razvoj bitna interakcija tih dvaju čimbenika ${ }^{45}$ što ujedno ruši i neke mitove o funkcioniranju mozga. ${ }^{46}$

\section{Didaktički elementi pravaca i pokreta reformne pedagogije}

Pojmu reformne pedagogije moguće je pristupiti na više načina. Jedan od načina je proučavanje povijesnog razdoblja pedagogije od otprilike kraja 19. stoljeća, pa do 1930 -ih godina.$^{47} \mathrm{~S}$ druge strane, moguće ga je tumačiti kao didaktičke i pedagoške koncepcije (didaktički elementi) koje su se pojavile u tom razdoblju, a koje su zadržane do danas. Ali, moguće ju je tumačiti s različitih teorijskih i praktičnih pristupa i kao trajnu perspektivu promišljanja učitelja o promjenama i poboljšanju nastave, obrazovanja i škole. ${ }^{48}$ Stoga, reformnu pedagogiju (ili reformne pedagogije - u pluralu) nije moguće jednoznačno definirati, ${ }^{49}$ a posebice ako je shvaćamo kao didaktičke i pedagoške koncepcije kojima je zajednički odmak od intelektualističkog naglaska »stare škole«, nastave usmjerene na učitelja te odmak od krutog razredno-predmetno-satnog sustava. ${ }^{50}$

Raspravljajući o pojavi, formiranju i razvoju reformne pedagogije te njenih didaktičkih i pedagoških koncepcija valja opisati društveni, gospodarski i kulturni kontekst vremena u kojem se ona pojavila. ${ }^{51}$ Druga je polovica 19. stoljeća obilježena industrijskom revolucijom koja je tražila velik broj fizičkih radnika, ali ih je istovremeno i dehumanizirala. Ljudi su u tvornicama i industriji radili više od dvanaest sati dnevno. Također, i djeca su bila izrabljivana u tvornicama kao fizički radnici. Dijete nije promatrano kao sebi svojstveno biće i sa specifičnim razvojnim fazama, već kao (odrasli) čovjek u malome. U političkom kontekstu, u svijetu (posebice u Europi) nastaje destabilizacija monarhija, političkog poretka i sustava vladavine, čime se uzrokuje neizbježnost Prvog svjetskog rata. U umjetnosti i kulturi javljaju se radikalno drugačiji pokreti koji prekidaju s tradicijom. U takvom turbulentnom političko-gospodarskom okruženju nastaju različiti društveni pokreti, kao što su pokret za ljudska prava,

\footnotetext{
${ }^{45}$ Usp. Pinel, nav. $d j ., 21-24$.

${ }^{46}$ Usp. John GEAKE, Neuromythologies in education, Educational research, 50 (2008) 2, 123 133; OECD, Understanding the brain. The birth of a learning science, 107-127.

${ }^{47}$ Usp. Herbert GUDJONS, Pädagogisches Grundwissen, Rosenburg, Klinkhard, 2012, 101-107.

${ }^{48}$ Usp. Terhart, nav. dj., 645-646.

${ }^{49}$ Usp. Gudjons, nav. dj., 101-107.

${ }^{50}$ Usp. Štefka BATINIĆ, Povijesni razvoj i recepcija reformne pedagogije u Hrvatskoj, doktorska disertacija, Zagreb, Filozofski fakultet Sveučilišta u Zagrebu, 2014; Skiera, nav. dj.

${ }^{51}$ Usp. Batinić, nav. dj.
} 
prava radnika, prava žena i sl. Nadalje, u tom se vremenu pojavljuju nehumane biološko-psihološko-medicinske ideje eugenike te različiti politički pokreti. U takvom okruženju oblikuje se reformna pedagogija.

Zbog ovakvog društveno-gospodarskog okruženja uviđa se potreba drugačijeg odgoja i obrazovanja te briga o djeci. Formalni poticaj nastanka reformne ili »nove« pedagogije jest (ponegdje i kontroverzno tumačena) ${ }^{52}$ knjiga »Stoljeće djeteta « ${ }^{53}$ švedske autorice Ellen Karoline Sofie Key (1849-1926) objavljene 1900. godine..$^{54}$ Polazeći od ideja Rousseaua, Pestalozzija i drugih njima sličnih pedagoga, Key je zagovarala pedocentrični pristup odgoju i obrazovanju djeteta. Njezin pedocentrizam je zbog nerazumijevanja posebnosti dječjeg razvoja često bio kritiziran, jer je bio odmaknut od ondašnjeg ustaljenog pogleda na dijete kao »čovjeka u malom«, generalno »zločestog« djeteta kojeg tek stegom treba »disciplinirati«. Keyin pedocentrizam je djelomično temeljen na i spoznajama onda mlade znanosti - razvojne psihologije. Spoznaje razvojne psihologije su ukazale na postojanje specifičnih faza dječjeg (čovjekovog) razvoja. Drugim riječima, uviđa se da je dijete sebi svojstveno biće, sa specifičnim i mijenjajućim karakteristikama odrastanja, čime su reafirmirane i potvrđene pedagoške ideje Pestalozzija i Rousseaua.

Upravo spoznavanje specifičnosti (faza) dječjeg razvoja je bio jedan od ključnih elemenata kod ondašnjih naprednih stručnjaka u odgoju i obrazovanju. Zato valja kazati da su za razvoj reformne pedagogije bile značajne spoznaje razvojne psihologije ${ }^{55}$ te formiranje pedagoške psihologije, tada zvane pedologija. ${ }^{56}$ Time je reformna pedagogija napravila otklon od tradicionalne normativne pedagogije koja je određivala što odgoj treba biti legitimiziranjem ciljeva i njenih sadržaja. Pedagoški oblikovne spoznaje razvojne psihologije su ukazivale da je dijete (čovjek), osim kognitivno, ujedno i čuvstveno i tjelesno biće. Tako su nastali pravci i pokreti koji su uvažavali sve aspekte dječjeg razvoja, a njima nije odgovarao razredno-predmetno-satni sustav nastave usmjerene na učitelja.

Prve kritike u odnosu na školu u kojoj se previše sjedi, sluša i uči glavom (intelektualistička škola) upućivali su Rousseau (1712-1778) i Pestalozzi (17461827). Rousseau je isticao da, osim intelektualnog odgoja, djeca trebaju radni odgoj te odgoj srca i dobrote. Smatra se da je Pestalozzi prvi istaknuo pedagoški

\footnotetext{
${ }^{52}$ Ellen Key i njezini radovi su obrađivani u društvenom, liberalnom i pedagoškom aspektu, ali su spominjani i u kontekstu propagiranja eugenike (usp. Mike HAWKINS, Social Darwinism in European and American thought, 1860-1945, Cambridge, Cambridge University Press, 1998).

${ }^{53}$ Usp. Ellen KEY, Stoljeće djeteta, Zagreb, Educa, 2000.

${ }^{54}$ Usp. Gudjons, nav. dj., 101-107.

${ }^{55}$ Usp. Stevan PATAKI, Problemi i pravci reformne pedagogije, Zagreb, Minerva, 1938; Mate ZANINOVIĆ, Opća povijest pedagogije, Zagreb, Školska knjiga, 1988.

${ }^{56}$ Svakako valja naglasiti da Stevan Pataki (usp. Pataki, nav. dj.), iako ukazuje na važnost spoznaja razvojne psihologije, nikako ne negira značenje same pedagogije, tj. on pedagogiju ne zamjenjuje psihologijom. Čak dapače, on argumentirano naglašava važnost pedagoškog definiranja ciljeva nastave i vrijednosnog određenja učenja, čime potvrđuje prvenstvo pedagogije u praksi i istraživanju odgoja i obrazovanja.
} 
moto: Uči se glavom, srcem i rukama (a ne samo glavom!). Kasnije će se te ideje ostvariti kod brojnih reformnih pedagoga i reformnih pedagoških projekata. Tako su nastali različiti pedagoški pravci i pokreti, a neki od njih su: »slobodna škola« Tolstoja, »škola po mjeri učenika« Claparedea, »slobodne grupe« Cousineta, »aktivna škola« Feriera, »spontani radni doživljaj« Kerschensteinera, »slobodni duhovni rad« Gaudiga, »slobodne radne grupe« Fickera, »slobodno razvijanje učenika« Litta, waldorfska škola i filozofija Rudolfa Steinera, škola i metoda Marije Montessori, pedagogija Celestina Freineta, Jena-plan Petera Petersena, pokret za umjetnički odgoj Avenariusa i Lichtwarka i dr. ${ }^{57}$ Ovdje ćemo ukratko opisati osnovna obilježja pojedinih pravaca i pokreta reformne pedagogije, a na kraju navesti neke njima zajedničke didaktičke elemente.

U literaturi ${ }^{58}$ se ističu zasluge književnika i pedagoga Lava Nikolajeviča Tolstoja koji je sredinom 19. stoljeća žestoko kritizirao nastavu u kojoj djeca danima sjede, slušaju i gledaju što i kako rade učitelji. On je smatrao to sputava njihov razvoj i ne zadovoljava njihove razvojne potrebe. U školi u kojoj je radio nudio je djeci više slobode u izvršavanju školskih obveza te ponašanju u učionici. Zbog takvih liberalno-slobodarskih ideja imao je velikih nesporazuma s predstavnicima školskih vlasti. Njegove su pedagoške ideje bile veliko ohrabrenje svim učiteljima da počnu sumnjati i preispitivati didaktičku paradigmu koja je razvijana na temeljima razredno-predmetno-satnog sustava. ${ }^{59}$ Tolstojeve slobodarske ideje se smatraju pretečom pokreta i pravaca reformnih pedagogija krajem 19. i početkom 20. stoljeća.

Naravno da je najžešća kritika u odnosu na školu i dominantne didaktičke scenarije 19. stoljeća dolazila iz područja industrijski najrazvijenijih dijelova svijeta, Europe i Amerike (SAD-a). Umjesto sjedilačko-slušalačke nastave u učionici koja je pripremljena za takve didaktičke scenarije, John Dewey (18521952) i brojni drugi reformni pedagozi u SAD-u zagovaraju projektno i problemsko učenje u laboratorijima i prirodi (npr. W. H. Kilpatrik, H. Parkhurst, K. Washburne i dr.). Umjesto učenja napamet onoga što su učitelji predavali ili što je bilo napisano u knjigama, Dewey i njegovi sljedbenici su zagovarali didaktičke scenarije u kojima učenici istražuju, otkrivaju, rade u grupama, rje-

\footnotetext{
${ }^{57}$ Usp. Milan MATIJEVIĆ, Alternativne škole. Didaktičke i pedagoške koncepcije, Zagreb, Tipex, 2001; Jürgen OELKERS, Reformpädagogik. Entstehungsgeschichten einer internationalen Bewegung, Zug, Klett und Balmer, 2010; Harm PASCHEN, Waldorf education and Rudolf Steiner schools as a topic of educational science, Croatian Journal of Education, 16 (2014) 1, 191-215; Pataki, nav. dj; Vlatko PREVIŠIĆ, Alternativne škole. Teorijska polazišta i praktični dosezi, u: Berislav LIČINA, Vlatko PREVIŠIĆ, Slavko VUČAK (ur.), Prema slobodnoj školi, Zagreb, Institut za pedagogijska istraživanja Filozofskog fakulteta Sveučilišta u Zagrebu, 1992 13-19; Skiera, nav. dj; Vera STEIN-EHRLICH, Metoda Montessori u školi, Zagreb, Minerva, 1934; Zaninović, nav. dj.

${ }^{58}$ Usp. Batinić, nav. dj.; Skiera, nav. dj.

${ }^{59}$ Usp. Jan Amos KOMENSKI, Didaktika, Zagreb, HPKZ, 1871.
} 
šavaju stvarne ili zamišljene probleme, rade na različitim projektima u školi ili u prirodi u blizini škole. ${ }^{60}$

Za odmak od intelektualističke škole 19. stoljeća na području Europe posebno su zaslužni Georg Kerschensteiner (1854-1932) i Hugo Gaudig (1860-1923). Umjesto predavačke nastave njih dvojica su zagovarali učenje radom, dakle aktivno učenje. Kerschensteiner je isticao pedagošku važnost ručnog rada, a Gaudig je naglašavao i važnost duhovnog rada. Njih dvojicu se smatra glavnim zagovornicima radne škole (škole rada) na području Europe, no ništa manje zasluge za radnu školu imaju i Maria Montessori, Rudolf Steiner, Celestin Freinet i brojni drugi predstavnici projekata koji su bliski idejama škole rada. ${ }^{61}$

Maria Montessori (1870-1952) je razvila cjelovit pedagoški model koji i danas egzistira po svijetu u obliku originalne alternativne škole. U osnovi te koncepcije je učenje rukama te manipuliranje originalnim nastavnim materijalima. Naglašena je poticajna obrazovna okolina te iskustveno i aktivno učenje uz pedagoški dobro odmjereno vođenje od strane učitelja. ${ }^{62}$

Rudolf Steiner (1861-1925) je utemeljio originalan model alternativne škole u kojoj su, umjesto predavačkih metoda, odnosno predavačko-prikazivačke nastave, dominantne raznovrsne intelektualne, fizičke i duhovne aktivnosti učenika. Sve aktivnosti koje nude Maria Montessori i Rudolf Steiner polaze od temeljitog proučavanja intelektualnog, fizičkog i duhovnog razvoja djeteta od rođenja do zrelosti. Zanimljivo je da su oboje veliku pozornost posvećivali promjeni, odnosno prilagodbi poticajne obrazovne okoline koja je bitno razlikuje u odnosu na onu u kojoj se događa predavačko-prikazivačka nastava. Zanimljivo je da je Steiner prije više od devedeset godina zagovarao važnost njegovanja i razvijanja fine motorike (npr. crtanje oblika i pletenje) te ručnog rada za razvoj djetetova mozga u početnim razredima obveznoga školovanja. ${ }^{63}$

Značajne su i ideje Celestina Freineta (1896-1966) te Petera Petersena (18841952). Oni su u svojim pedagoškim radovima zagovarali suradničko učenje, učenje igranjem te projektno i iskustveno učenje kao i učenje rukama. ${ }^{64}$

Ne znamo kako su međusobno komunicirali vodeći pedagozi i predstavnici pokreta i pravaca reformne pedagogije, ali na temelju ideja koje su zagovarali razvidno je da su se međusobno dobro poznavali. Krajem 19. i početkom 20. stoljeća pisane poruke su putovale prilično dugo, obično trideset do šezdeset dana. Nijemac Georg Kerschensteiner, Amerikanac John Dewey, Autrijanac Rudolf Steiner, Talijanka Maria Montessori su rođeni u istom desetljeću (između 1860. i 1870. godine). U njihovim životopisima je zapisano da su prilično putovali. Kerschensteiner je posjetio Francusku, Švicarsku, Rusiju, SAD radi

\footnotetext{
${ }^{60}$ Usp. isto; Topolovčan, Rajić, Matijević, nav. dj., 65-104.

${ }^{61}$ Usp. Skiera, nav. dj.

${ }^{62}$ Usp. Marielle SEITZ, Ursula HALLWACHS, Montessori ili Waldorf? Knjiga za roditelje, odgajatelje i pedagoge, Zagreb, Educa, 1997; Stein-Ehrlich, nav. dj.

${ }^{63}$ Usp. Seitz, Hallwachs, nav. dj.

${ }^{64}$ Usp. Matijević, nav. dj.; Topolovčan, Rajić, Matijević, nav. dj., 85-94.
} 
proučavanja školstva. Dewey je proučavao Hegela, a posjetio je Kinu, Tursku, Meksiko i druga mjesta. Maria Montessori je jednu od svojih prvih knjiga objavila i na engleskom jeziku. ${ }^{65}$ Osim toga, putovala je te boravila i djelovala $u$ Italiji, Španjolskoj, Nizozemskoj, SAD-u te Indiji. Kerschensteiner je putovao $\mathrm{u}$ više srednjoeuropskih država te u SAD i Rusiju radi proučavanja njihova školstva. Tako su svi oni putujući, nastupajući na javnim skupovima držanjem predavanja ili (vjerojatno) međusobnim dopisivanjem i proučavanjem objavljenih radova upoznavali reformne ideje i doprinosili da one zažive i šire se po školama na području Europe i SAD-a. ${ }^{66}$

Već smo spomenuli da se uz reformne ideje početkom proteklog stoljeća vezuju izrazi radna škola, aktivna škola, nova škola, slobodna škola, problemska nastava, projektna nastava i sl. U svim tim didaktičkim i pedagoškim paradigmama uočavamo elemente koji u konstruktivističkoj nastavi i kurikularnim teorijama bivaju ostvarivane u obliku suradničkog, problemskog, projektnog, odnosno aktivnog i iskustvenog učenja.

Analizirajući i sumirajući obilježja različitih pravaca i pokreta reformne pedagogije, možemo ukazati na neke bitne zajedničke elemente kao što su: učenje istraživanjem i otkrivanjem; učenje rješavanjem problema; učenje igrom; projektno učenje; suradničko učenje; djelovanju usmjereno učenje. ${ }^{67}$

Vidljivo je da se su ove strategije utemeljene na onome što se naziva iskustveno učenje koje je u suprotnosti s nastavom usmjerenom na učitelja te naglaskom na samo intelektualističke škole. ${ }^{68}$

\section{Zaključak}

Teorijsko-komparativnom i povijesnom analizom nastanka i svojstava konstruktivizma u didaktici, zatim obrazovne neuroznanosti, tj. neurodidaktike, te pravaca i pokreta reformne pedagogije, moguće je sintetizirati nekoliko razlika, ali i bitnih zajedničkih elemenata. Konstruktivizam, obrazovna neuroznanost te pravci i pokreti reformne pedagogije pojavili su se u različitim povijesnim momentima kao posljedica promjene društvenih, tehnoloških, znanstvenih, političkih, kulturnih i gospodarskih okolnosti.

Istraživanja mozga imaju višetisućljetnu povijest, ali pojam obrazovne neuroznanosti, neurodidaktike ili poučavanja s mozgom na umu - aktualiziran je u posljednjih nešto više tri desetljeća. Može se kazati da je to posljedica znan-

\footnotetext{
${ }^{65}$ Usp. Maria Montessori, Dr. Montessori own handbook, Cambridge, MA, Robert Benteley, Inc., $1914 / 1964$

${ }^{66}$ Usp. Oelkers, nav. dj.; Skiera, nav. dj.

${ }^{67}$ Usp. Topolovčan, Rajić, Matijević, nav. dj., 58, 116.

${ }^{68}$ Usp. Oelkers, nav. dj.; Skiera, nav. dj.
} 
stvenih i tehnoloških inovacija $u$ istraživanju mozga (PET i MRI metode) te didaktičkih interesa za novim razumijevanjima i objašnjenjima nastave.

Pravci i pokreti reformne pedagogije pojavili su se prije nešto više od stotinjak godina, s prijelaza 19. u 20. stoljeće. Snažan impuls za njihovo pojavljivanje vidljiv je u društvenim, političkim, kulturnim i gospodarskim okolnostima tog vremena. S druge strane, snažan utjecaj na razvoj reformne pedagogije imala je razvojna psihologija, ali i ideje Pestalozzija, Rouessaua i dr. Koncept reformne pedagogije je moguće višeznačno tumačiti, tj. kao povijesnu epohu pedagogije, didaktičke elemente i koncepcije te stalnu težnju za promjenama i poboljšanjem nastave.

Konstruktivizam nije moguće definirati s jednog aspekta, pa se u tom pogledu govori o filozofskoj teoriji stvarnosti i znanja, psihološkoj teoriji učenja i didaktičkoj teoriji nastave. U skladu s time povijesno se i pojavljuje u različito vrijeme. S filozofskog aspekta datira od vremena prije Krista, iako sam pojam $» k o n s t r u k t i v i z a m$ « nastaje prije pedesetak godina u vidu psihološkog pristupa (koji u anglosaksonskom govornom području zauzima bitnu ulogu u obrazovnom kontekstu, za razliku od srednjoeuropskog, tj. njemačkog govornog područja). S didaktičkog povijesnog aspekta, konstruktivizam nije doslovno tako terminološki nazvan, ali je prepoznat u idejama pojedinih pedagoga, a posebice u nastavnoj praksi zadnjih stotinjak godina kao odmaka od »stare škole« (zbog komparacije detaljno objašnjeno u nastavku).

Analizirana obilježja konstruktivizma i istraživanja mozga ukazuju na važnost aktivnosti učenika, društvenih interakcija, pozitivnih emocija, smanjenju stresa, poticajne okoline, individualnog i socijalnog konstruiranja vlastitog znanja, vrijednosnog i kulturološkog određenja, holističkog pristupa i razvoja, tjelesnog kretanja, refleksije i praktičnosti u procesima učenja i nastave. Kada se ta obilježja implementiraju u didaktički teorijski, metodološki i praktični okvir, možemo govoriti o učenju rješavanjem problema, učenju istraživanjem, učenju koje je usmjereno na djelovanje, učenju igrom te suradničkom i projektnom učenju. Drugim riječima, i konstruktivistička didaktika i neurodidaktika, ukazuju na iste ili slične strategije učenja i obilježja nastave. Ta su nastavna obilježja i strategije učenja otprije poznate u povijesti pedagogije. Ona su utvrđena prije više od sto godina u pravcima i pokretima reformne pedagogije, odnosno u idejama Steinera, Montessori, Deweya, Gaudiga, Freineta, Litta i dr. Stoga je važno ukazati na to da konstruktivistička didaktika i neurodidaktika nisu sadržajno, potpuno novi koncepti, već dobrim dijelom preuzimaju poznate didaktičke elemente pravaca i pokreta reformne pedagogije. Možemo kazati da se konstruktivistička didaktika, koja svojom ponudom didaktičkih strategija i scenarija značajno zadovoljava očekivanja koja postavljaju istraživači iz područja obrazovne neuroznanosti (neurodidaktike), bitno oslanja na ideje reformnih pedagogija. 
Svakako, to ne umanjuju aktualnost konstruktivističkog pristupa i značenje neuroznanstvenih spoznaja. Upravo suprotno, spoznaje razvojne psihologije (konstruktivističke psihološke teorije), a posebice istraživanja mozga i općenito neuroznanosti, ukazuju na potrebne novine u procesima učenja, poučavanja i nastave. Nadalje, obrazovna neuroznanost ukazuje i na neke mitove te zablude u nastavi i obrazovanju (korišteni kapacitet mozga, dominacija lijeve ili desne hemisfere mozga, stilovi učenja i dr.). Neka od najznačajnijih obilježja obrazovne neuroznanosti je što potvrđuje visoku didaktičku vrijednost nastave usmjerene na učenika (konstruktivistička nastava i didaktički elementi reformne pedagogije).

S druge strane, konstruktivistička didaktika i neurodidaktika, kao i pravci i pokreti reformne pedagogije, potvrđuju malenu didaktičku vrijednost frontalne i predavačke nastave, tj. nastave usmjerene na nastavnika i realizaciju programa. Nadalje, konstruktivističku didaktiku i neurodidaktiku nije moguće definirati kao vremenske (povijesne) faze didaktike makar se pojavljuju $\mathrm{u}$ različitim vremenskim momentima i teorijsko-praktičnim formama, dok je to moguće učiniti za reformnu pedagogiju. Ali, konstruktivističku didaktiku i neurodidaktiku je moguće razumjeti kao stalnu težnju poboljšanja i reforme nastave, isto kao što je moguće na taj način pristupati objašnjenju reformne pedagogije.

Na kraju, opravdano je ukazati da prikazana obilježja, spoznaje i interpretacije konstruktivističke didaktike i neurodidaktike u diskursu didaktičkih elemenata reformne pedagogije mogu činiti uporišta za način (re)definiranja teorijskog, metodološkog i praktičnog promišljanja suvremene nastave, ali i nastave u budućnosti. 


\section{Nevenka Maras* - Tomislav Topolovčan ${ }^{* * *}$ - Milan Matijevićs*** \\ Constructivist didactics and neurodidactics in discourse of the reform pedagogy. Theoretical premises, dilemmas and comparison}

\section{Summary}

This work elaborates concepts of constructivism and neurodidactics and directions and movements of the reform pedagogy as defined, explained and brought into relations by critical comparative and historical analysis. Primarily, characteristics, definitions and the development of constructivism and neurodidactics have been explained. Special emphasis has been put on current neuroscientific understandings on methods and processes of learning and their implications in didactic theories and their manifestations in the organisation of learning and teaching. The analisys has shown that some of the ground characteristics of constructivism and neurodidactics are visible in learning strategies such as: inquiry-based learning, problem-based learning, collaborative learning, learning-by-doing, play-based learning and project-based learning. In other words, strategies involving student-centred teaching. Apart from these characteristics being common for both constructivism and neurodidactics, they are not entirely novelties that originated from these concepts alone. Further analysis showed that these didactic characteristics have been recognized, i.e. formed more than century ago in the directions and movements of the reform pedagogy. With respect, it is justifiable to conclude that the characteristics that have been deemed as constructivist teaching, are already present in the reform pedagogy. Likewise, it is reasonable to conclude that the neuroscientific research, besides offering new insights on learning processes, also confirm the didactic value of directions and movements of the reform pedagogy at the turn of the $20^{\text {th }}$ century. Given the mutual compatibility of the concepts analysed in this work, further critical and arguments supported synergy is something to aspire to, with the intention of improvement and advancement of the organising of the learning, teaching and instruction processes.

Key words: constructivism, didactics, educational neuroscience, reform pedagogy, teaching.

(na engl. prev. Nevenka Maras)

\footnotetext{
* Nevenka Maras, PhD, Assis. Prof., Faculty of Teacher Education, University of Zagreb; Address: Savska cesta 77, HR-10000 Zagreb, Croatia; E-mail: nevenka.maras@ufzg.hr.

* Tomislav Topolovčan, PhD, Assis. Prof., Faculty of Teacher Education, University of Zagreb; Address: Savska cesta 77, HR-10000 Zagreb, Croatia; E-mail: tomislav.topolovcan@ufzg.hr.

***: Milan Matijević, PhD, Full Prof., Faculty of Teacher Education, University of Zagreb; Address: Savska cesta 77, HR-10000 Zagreb, Croatia; E-mail: milan.matijevic@ufzg.hr.
} 